\title{
Menurunkan tingkat depresi melalui acceptance and commitment therapy (ACT) pada ODHA
}

\author{
Jatu Anggraenia,1, Sulistyo Budiarto ${ }^{b, 2 *}$ \\ a,bFakultas Psikologi, Universitas Sarjanawiyata Tamansiswa, Yogyakarta \\ 1Jatu.anggraeni@ustjogja.ac.id; *2st.budiarto@ustjogja.ac.id \\ *Correspondent Author
}

KATAKUNCI ABSTRAK

acceptance and commitment therapy;

depresi;

ODHA (orang dengan HIV-

AIDS)

\section{KEYWORDS}

acceptance and commitment therapy;

depression;

PLWHA (people living with HIV AIDS)
Acceptance and commitment therapy merupakan intervensi yang dapat mempengaruhi penurunan tingkat depresi pada ODHA. Penelitian ini bertujuan untuk mengetahui efektifitas acceptance and commitment therapy dalam menurunkan tingkat depresi ODHA. Penelitian ini menggunakan metode kuantitatif dengan desain penelitian kuasi ekperimen one-group pretest-posttest design. Subjek dalam penelitian ini berjumlah enam orang. Alat ukur yang digunakan dalam penelitian ini adalah instrument DASS 42. Hasil dari penelitian ini menyimpulkan bahwa ACT efektif dalam menurunkan tingkat depresi ODHA, penurunan tingkat depresi tersebut terlihat dari adanya perbedaan yang signifikan antara skor depresi saat pretest dengan posttest. Nilai $\mathrm{Z}=-2,201$ dengan $\mathrm{p}=0,028$ dan terjadi penurunan antara mean pretest dan mean posttest, sehingga ACT dapat diberikan sebagai salah satu metode program pemulihan bagi ODHA.

\section{Reducing depression levels through acceptance and commitment therapy (ACT) in PLWHA}

Acceptance and commitment therapy is an intervention that can affect the decrease in depression levels in PLWHA. This study aims to determine the effectiveness of acceptance and commitment therapy in reducing depression levels of PLWHA. This study uses a quantitative method with a quasi-experimental one-group pretest-posttest design. The subjects in this study amounted to six people. The measuring instrument used in this study is the DASS 42 instrument. The results of this study conclude that ACT is effective in reducing depression levels of PLWHA, the decrease in depression levels can be seen from the significant difference between depression scores at pretest and posttest. $Z$ value $=-2.201$ with $p=0.028$ and there is a decrease between the mean pretest and mean posttest, so that ACT can be given as a method of recovery program for PLWHA.

This is an open-access article under the CC-BY-SA license.

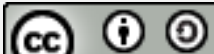

\section{Pendahuluan}

Individu dan setiap orang pada umumnya menginginkan kehidupan yang bahagia. Begitu 
juga dengan individu yang mendapatkan diagnosa HIV-AIDS atau sering disebut dengan ODHA (Orang dengan HIV-AIDS). Istilah ODHA digunakan untuk menggantikan kata penderita yang menunjukkan pada pengertian individu dengan diagnosis reaktif HIV-AIDS. Kenyataan yang terjadi bahwa individu yang mendapatkan diagnosa mempunyai HIV-AIDS dan memiliki berbagai penyakit penyerta akibat virus tersebut banyak yang merasa putus asa. Rasa putus asa lebih lanjut diikuti dengan munculnya rasa sedih berkepanjangan, hingga mengarah pada gejala depresi. Bahkan sampai dengan merasa kehilangan makna hidup sehingga seringkali terpikir untuk mengakhiri hidup.

Ada banyak faktor yang memengaruhi rasa putus asa yang dimiliki ODHA, dua diantaranya karena sampai dengan saat ini belum ditemukan obat untuk menyembuhkan penyakit tersebut, selain itu stigma negatif masyarakat. Sesuai dengan yang disampakan Ardani dan Handayani (2017); Shaluhiyah, Musthofa, dan Widjanarko (2015); bahwa stigma dari HIV-AIDS akan membawa dampak negatif pada individu yang mengalami tanpa memandang jenis penyakitnya. Dampak ini tentu saja dapat mempengaruhi motivasi untuk memperoleh pemulihan ODHA, yang pada giliranya dapat berdampak buruk bagi proses pengobatan yang mereka jalani. Penerimaan diri (self aceptance) merupakan kemampuan yang dimiliki seorang individu dalam menyadari dan mengakui karakteristik dirinya pada saat menjalani hidup tanpa terbebani oleh perasaan terhadap dirinya sendiri. Peneriman diri yang kurang bahkan cenderung merasa berdosa, bersalah, malu dan tidak pantas untuk meneruskan hidup akan berdampak pada diri individu tersebut sehingga menjadi tidak mampu menerima keberadaan dirinya sendiri dan mengarah pada gejala depresi.

Permasalahan serupa terjadi pada ODHA yang telah menjalani terapi ARV (antiretroviral). Pada ODHA lama seringkali mengalami depresi karena kejenuhannya menjalani pengobatan. Hal tersebut terlihat dari perilaku individu tersebut yang sering menangis tanpa sebab jelas, histeris, linglung, mengurung diri, tidak ingin bersosialisasi dengan masyarakat, tidak ingin melakukan aktivitas, dan dalam dirinya penuh rasa jengkel serta kemarahahan terhadap diri sendiri maupun orang lain. Keadaan demikian tetap terjadi meskipun banyak kegiatan yang sudah diikuti terkait dengan edukasi tentang HIV-AIDS. Oleh karena itu penelitian terhadap HIV-AIDS menjadi hal yang sangat penting untuk mendapatkan alternatif solusi terbaik yang dapat digunakan secara praktis.

Depresi sendiri merupakan suatu periode dimana terjadi gangguan fungsi pada diri individu yang dikaitkan dengan perasaan yang sedih serta gejala penyertanya, seperti perubahan pola makan, psikomotor, konsentrasi, rasa lelah, anhedonia, rasa tak berdaya, putus asa dan bunuh diri (Kaplan, Saddock, \& Grebb, 2010). Depresi ini dapat terjadi pada siapa saja tidak memandang pendidikan, etnik, usia, penghasilan maupun status perkawinan. Gejala-gejala depresi dapat dilihat pada kesedihan menetap, kehilangan minat atau kesenangan pada aktivitas menyenangkan, perubahan drastis pada nafsu makan atau berat badan, gangguan tidur, terjadi agitasi, kehilangan energi, merasa tidak berharga, kesulitan konsentrasi, dan muncul gagasan bunuh diri. Menurut Hope dan Henderson (2014) dalam penelitian klinis, genetik dan neuroscience memperlihatkan bahwa depresi merupakan satu bentuk kelainan pada otak. Beberapa tipe depresi seperti bipolar dan depresi mayor dapat dipengaruhi oleh genetik. Pada umumnya individu yang memiliki self-esteem rendah, mudah cemas dan rendah diri cenderung mengalami depresi. Individu dengan depresi biasanya mempunyai kontrol diri rendah dimana mereka memiliki penilaian diri dengan buruk, tingkat performance rendah, cenderung menyalahkan diri sendiri, serta tidak menghargai dirinya.

Mengacu pada literatur yang ada, bahwa depresi dapat diatasi dengan Acceptance and Commitment Therapy (ACT), karena berdasarkan literatur yang ada menunjukkan bahwa kasus-kasus seperti depresi, kecemasan, stress ataupun kelelahan dapat diatasi menggunakan ACT secara efektif. ACT sendiri merupakan terapi yang pertama kali dikembangkan oleh Steven Hayes dan Kellyy Wilson bersama dengan Krik Strosal di Amerika Serikat. Terapi ini terbentuk berdasarkan intervensi psikologi yang menggunakan strategi acceptance dan mindfulness dikolaborasikan dengan cara berbeda dengan commitment dan 
strategi perubahan perilaku. Hasil dari ACT adalah mampu membantu individu dengan rentang masalah yang bervariasi seperti depresi, gangguan cemas, gangguan zat adiktif, dan PTSD. (Davis, Deane, \& Lyons, 2019; Hayes, Steven, Smith, 2005; Hayes, Strosahl, Bunting, Twohig, \& Wilson, 2004; Tania \& Hernawaty, 2018)

Objek dari ACT bukan menghilangkan perasaan buruk atau tidak menyenangkan, akan tetapi lebih pada menerima kemana kehidupan berjalan (Hayes, Steven, Strosahl, Kirk, \& Wilson, 2016). Hal ini sesuai dengan pendapat Fledderus, Bohlmeijer, Pieterse, dan Schreurs (2012) bahwa ACT dapat diberikan pada berbagai macam kondisi seperti depresi dan kecemasan. Pada penelitian tersebut juga menunjukkan bahwa ACT efektif digunakan sebagai intervensi awal orang dengan tanda-tanda depresi ringan sampai dengan sedang. Penelitiannya juga membuktikan bahwa intervensi ACT juga dapat dipengaruhi tanda-tanda kecemasan dan kelelahan. Hayes, Luoma, Bond, Masuda, dan Lillis (2006) menyatakan bahwa target dari ACT adalah meningkatkan fleksibilitas psikologis, yaitu kemampuan individu dalam membangun kontak dengan masa kini secara totalitas, sadar sebagai mahkluk hidup, dan mampu berperilaku sesuai dengan nilai-nilai hidup yang diyakini.

Menurut Harris (2006) ACT bertujuan untuk menghasilkan kehidupan yang bermakna dengan melakukan penerimaan terhadap rasa sakit yang tidak dapat dihindari. ACT menjadi metode terapi yang dirancang khusus untuk mengurangi traumatik dan kecemasan tanpa harus menghindari pengalaman (Fashler Weinrib, Azam, \& Katz, 2018; Orsillo \& Batten, 2005). Menurut Kusumawardhani dan Poerwandari (2019), ACT lebih banyak menggunakan metafora, ketrampilan mindfulness dengan latihan eksperimental secara bersamaan dengan tujuan agar individu dapat memahami lebih dalam tentang makna dari konsep yang disampaikan oleh terapis sebagai pemberi intervensi. Terapi ini tidak banyak mengajak individu untuk melakukan penentangan ataupun restrukturisasi pikiran seperti halnya pada Cognitif Behaviour Therapy (CBT).

Berdasarkan paparan sebelumnya, maka penelitian ini bertujuan untuk mengetahui penurunan tingkat depresi melalui Aceptance and Commitment Therapy pada ODHA. Penelitian ini diharapkan dapat memberikan sumbangan dalam perkembangan ilmu dan praktik di bidang ilmu psikologi klinis. Selain itu, ACT dapat menjadi alternatif intervensi untuk menurunkan tingkat depresi atau bahkan menghilangkan depresi pada ODHA lainnya.

\section{Metode}

Metode yang digunakan pada penelitian ini adalah kuantitatif dengan eksperimen onegroup pretest-posttest design. Subjek dalam penelitian ini melibatkan enam orang ODHA, dengan karakteristik sebagai berikut: 1) perempuan; 2) sudah menikah; 3) pendidikan minimal SMA; 4) diagnosa minimal lebih dari 1 tahun; 5) domisili DIY; 6) usia antara 23-45 tahun. Instrumen penelitian menggunakan DASS 42 (Depression Anxiety Stress Scale) yang dikembangkan oleh Lovibond dan Lovibond tahun 1995. Instrumen DASS 42 terdiri dari 42 item pertanyaan, yang mencakup tiga sub variabel diantaranya fisik, emosi/psikologis dan prilaku. Peneliti menggunakan instrumen DASS 42 karena DASS 42 berisi pernyataan yang singkat sehingga dapat di sesuaikan dengan subjek penelitian yang berkisar antara usia 2345 tahun. Tingkatan depresi pada instrumen DASS 42 menggolongkan pada lima tingkatan yaitu: normal, mild, moderate, severe, dan extremely severe atau dapat dikatakan tingkatan normal, ringan, sedang, berat, dan sangat berat. Dikatakan normal apabila skor 0-9, ringan apabila skor 10-13, sedang apabila skor 14-20, berat apabila skor 21-27, dan sangat berat apabila skor $>28$ (Crawford \& Henry, 2003). Adapun alternatif jawaban yang digunakan dan skala penilaiannya adalah sebagai berikut:

$0=$ Tidak sesuai dengan saya sama sekali, atau tidak pernah.

$1=$ Sesuai dengan dialami sampai tingkat tertentu, atau kadang-kadang.

$2=$ Sesuai dengan saya sampai batas yang dapat dipertimbangkan, atau sering.

$3=$ Sangat sesuai dengan saya, atau sering sekali 
Adapun tahapan yang dilakukan pada penelitian ini terdiri dari tiga tahapan, yaitu tahap awal, tahap intervensi, dan tahap akhir. 1) Tahap awal merupakan tahap persiapan, dimana peneliti memberikan pretest berupa skala DASS 42 untuk melihat tingkat depresi pada masing-masing subjek. Berdasarkan hasil skor tersebut peneliti menggunakan enam subjek yang memenuhi kriteria depresi untuk diberikan intervensi. 2) Tahap intervensi yang digunakan adalah Acceptance and Commitment Therapy yang dilakukan sebanyak tujuh sesi selama satu bulan dimana masing-masing pertemuan dilaksanakan selama 120 menit. Adapun prosedur yang dilakukan dalam setiap sesi adalah: a) persiapan: b) tahap orientasi; c) tahap kerja, dan d) tahap terminasi. Adapun sesi-sesi terapi adalah sebagai berikut: a) kontrak dan memabngun kerjasama; b) memahami kondisi diri dengan identifikasi kejadian, pikiran dan perasaan; c) difusi kognitif; d) accepting and midfullning; e) menemukan nilai positif; f) commitment; g) evaluasi dan terminasi. 3) Tahap akhir setelah intervensi untuk menutup seluruh kegiatan intervensi adalah dengan memberikan post-test dengan skala yang sama yaitu DASS 42. Proses terakhir yaitu follow up yang bertujuan meninjau kemajuan pada subjek pada intervensi yang sudah dilakukan.

\section{Hasil}

Penelitian ini dilakukan di sebuah yayasan pendampingan ODHA di kota Yogyakarta pada bulan Februari. Asesemen awal dilakukan pada ODHA yang berada dalam pendampingan yayasan tersebut. Skrining awal dilakukan pada 15 orang dan terpenuhi kriteria 10 orang. Akan tetapi yang bersedia mengikuti intervensi sampai dengan hari yang sudah ditentukan hanya tersisa enam orang. Penelitian ini dilakukan selama empat minggu dengan tujuh kali pertemuan dan enam kali sesi terapi. Adapun karaketristik subjek penelitian dapat dilihat pada tabel 1 .

Tabel 1.

Karakter Partisipan Penelitian

\begin{tabular}{ll}
\hline Karakateristik Demografis & Jumlah subjek terpakai (N=6) \\
\hline $\begin{array}{l}\text { Jenis kelamin } \\
\text { Perempuan } \\
\text { Diagnosis }\end{array}$ & $6(100 \%)$ \\
$\begin{array}{l}\text { ODHa } \\
\text { Menjalani perawatan }\end{array}$ & $6(100 \%)$ \\
ARV & \\
Usia & $6(100 \%)$ \\
$24-38$ & \\
$39-45$ & $5(100 \%)$ \\
Status Pernikahan & $1(100 \%)$ \\
Menikah & \\
Belum menikah & $6(100 \%)$ \\
\hline
\end{tabular}

Uji hipotesis pada penelitian ini menggunakan uji Wilcoxon untuk mengukur signifikansi perbedaan nilai sebelum dan sesudah pemberian perlakuan kepada subjek. Terdapat dua kaidah menerima hipotesis dalam uji Wilcoxon, pertama $\mathrm{p}<0,05$ dan searah dengan hipotesis Mean Pretest $>$ Mean Posttest. Hasil pengujian sebelum dan sesudah pemberian perlakuan menggunakan intrumen DASS 42 dapat dilihat pada tabel 2. 
Tabel 2.

Hasil Perbedaan sebelum dan sesudah ACT

\begin{tabular}{llllll}
\hline \multirow{2}{*}{ Variabel } & Jumlah Subjek (N) & \multicolumn{2}{c}{ Mean } & \multirow{2}{*}{ Z } & \multirow{2}{*}{ Sig.(p) } \\
\cline { 3 - 4 } & & Pretest & Posttest & & \\
\hline Depresi & 6 & 22,00 & 12,67 & $-2,201$ & 0,028 \\
Kecemasan & 6 & 16,00 & 8,50 & $-2,201$ & 0,028 \\
Stres & 6 & 27,50 & 17,00 & $-2,214$ & 0,027 \\
\hline
\end{tabular}

Hasil uji pada tabel 2 menunjukkan terdapat perbedaan nilai signifikansi pada ketiga variabel yaitu depresi, kecemasan dan tingkat stress dari hasil skor sebelum dan sesudah pada subjek penelitian. Pada variabel depresi menunjukkan nilai $\mathrm{Z}=-2,201$ dengan $\mathrm{p}=0,028$ dan terjadi penurunan antara mean pretest dan mean posttest. Hasil mean pretest variabel depresi adalah sebesar 22,00, smeentara mean posttest sebesar 12,67. Pada variabel kecemasan menunjukkan nilai $\mathrm{Z}=-2,201$ dengan $\mathrm{p}=00,028$ dan terjadi penurunan antara mean pretest dan mean posttest. Mean pretest pada variabel kecemasan adalah sebesar 16,00, sementara mean posttest sebesar 8,50. Pada variabel stres menunjukkan nilai $\mathrm{Z}=-2,214$ dengan $\mathrm{p}=0,027$ dan terjadi penurunan antara mean pretest dan mean posttest. Mean pretest variabel stress adalah sebesar 27,50, sedangkan mean posttest sebesar 17,00.

\section{Pembahasan}

Hasil penelitian menunjukkan bahwa ACT dapat menurunkan tingkat depresi pada ODHA. Berdasarkan pengisian DASS 42 dan wawancara terhadap subjek, diperoleh gambaran bahwa subjek merasa mampu menerima pengalaman-pengalaman yang tidak menyenangkan ataupun pengalaman buruk saat mendapat diagnosa HIV-AIDS dan menjalankan perawatan. Subjek mulai membuka diri untuk belajar hidup dengan mengalami semua kejadian buruk dalam hidupnya dengan tidak berfokus pada menurunkan penyebab atau stresor, justru menjadikan stresor sebagai bagian dari hidupnya. Hasil studi ini sejalan dengan penelitian sebelumya yakni ACT terbukti mampu menurunkan kecemasan pada napi perempuan (Tania \& Hernawaty, 2018); kecemasan pasien dengan Hemodialisa (Ismoyowati, 2018)

Pada penelitian ini ,subjek merasa lebih rela untuk menghadapi pikiran, perasaan dan pengalaman yang selama ini justru dihindari. Hal inilah yang disebut prinsip acceptance, ketika subjek dapat melakukan penerimaan maka selanjutnya subjek dapat mengurangi penolakan secara emosional. Dimana ketika subjek menolak untuk mengalami pengalaman buruk yang biasanya subjek lakukan dengan cara menghindari masalah atau stresor melalui pikiran, perasaan dan perilaku. Melaui ACT, subjek cenderung melakukan koping untuk menghadapi stresor tersebut (Hayes, dkk., 2016).

Tahap selanjutnya subjek merasa mengalami kejadian seutuhnya tanpa harus melawan pada saat muncul kejadian yang membuat mereka merasa tidak nyaman. Dalam hal ini, subjek akan bercerita tentang pengalaman yang mereka alami, serta belajar untuk mengidentifikasi dan menjelaskan pikiran atau perasaan sampai dapat memahami diri sendiri. Subjek menjelaskan bahwa dengan ACT, mereka dapat menghadapi segala permasalahan lebih langsung sehingga perilaku yang dihasilkan dapat fleksibel dan konsisten terhadap nilai yang telah dimiliki sebelumnya. Menurut Luoma dan Platt (2014) kondisi ini disebabkan adanya proses mindfullness dalam proses ACT.

Subjek juga merasa menjadi lebih ramah terhadap diri mereka sendiri tanpa harus menghakimi atau menghubungkan diri sendiri dengan nilai benar atau salah. Subjek merasa lebih fokus pada diri sendiri dengan cara melatih pikiran, perasaan dan pengalaman. Subjek berlatih bahwa ketika muncul pikiran buruk atau tidak menyenangkan maka hal tersebut tidak akan mempengaruhi mereka. Dengan demikian apapun yang dipikirkan ataupun yang dirasakan tidak akan mempengaruhi pikiran ataupun emosi mereka. Hal ini sejalan dengan temuan Yadavaia, Hayes, \& Vilardaga (2014) yang menjelaskan bahwa pikiran dan emosi 
negatif dapat dilepaskan dengan adanya fleksibilitas psikologis yang difasilitasi oleh ACT.

ACT membantu subjek mengklarifikasi nilai yang ada di dalam hidup mereka selama ini, dan membantu dalam mengambil keputusan atau tindakan yang mendukung nilai-nilai hidup yang sudah dianut sejak sebelumnya. Pada penelitian ini subjek belajar untuk menggunakan nilai yang sudah ada untuk mengatasi permasalahan yang sedang dihadapi saat ini. ACT juga membantu subjek mengklarifikasi nilai-nilai tersebut apakah sudah tepat untuk digunakan, sehingga subjek merasa keinginan mereka lebih meningkat untuk melakukan perilaku baru yang adaptif.

Terakhir adalah adanya commited action dimana subjek merasa lebih berkomitmen untuk melakukan tindakan yang sesuai dengan nilai mereka sendiri. Subjek dapat fokus mengontrol secara verbal sekaligus melakukan tindakan atau perilaku yang sesuai dengan apa yang sudah diverbalkan mereka.

\section{Simpulan}

Penelitian ini menunjukkan bahwa ACT memiliki pengaruh pada penurunan tingkat depresi ODHA. Artinya, ACT mampu menurunkan tingkat depresi pada ODHA dan memberikan pemahaman mengenai kondisi diri yang lebih baik dari sebelumnya. Penelitian ini diharapkan mampu memberikan manfaat pada bidang ilmu psikologi klinis untuk menangani ODHA yang memiliki gejala depresi ringan dan sedang. Kelebihan ACT adalah mengajarkan individu dalam mengelola serta mengontrol pikirannya dalam menjalankan terapi ARV (antiretroviral) serta mengahadapi stigma dan diskriminasi, sehingga mampu menerima dirinya saat ini dan mengurangi persepsi negative terhadap penilaian orang lain terhadap ODHA. ACT juga dapat digunakan dalam membantu mengelola emosi terhadap perubahan yang dialami individu. Keterbatasan penelitian ini adalah peneliti menggunakan pengembangan terapi yang belum bayak digunakan sehingga masih perlu dikaji ulang dan diterapkan pada subjek yang beragam untuk melihat efektifitas terapi ACT tersebut. Bagi peneliti berikutnya dapat mengembangkan, mereplikasi ataupun mengaplikasin ACT ini kepada subjek dengan karakteristik yang hampir sama ataupun berbeda.

\section{UCAPAN TERIMAKASIH}

Ditujukan kepada Yayasan Victory Plus yang telah terlibat membantu terlaksananya penelitian ini.

\section{DAFTAR PUSTAKA}

Ardani, I., \& Handayani, S. (2017). Stigma terhadap orang dengan HIV/AIDS (ODHA) sebagai hambatan pencarian pengobatan: Studi kasus pada pecandu narkoba suntik di Jakarta. Buletin Penelitian Kesehatan, 45(2), 81-88. doi: 10.22435/bpk.v45i2.6042.81-88.

Crawford, J. R., \& Henry, J. D. (2003). The depression anxiety stress scales (DASS): Normative data and latent structure in a large non-clinical sample. British Journal of Clinical Psychology, 42(2), 111-131. doi: 10.1348/014466503321903544.

Davis, E. L., Deane, F. P., \& Lyons, G. C. B. (2019). An acceptance and commitment therapy selfhelp intervention for carers of patients in palliative care: Protocol of a feasibility randomised controlled trial. Journal of Health Psychology, 24(5), 685-704. doi: $10.1177 / 1359105316679724$.

Fashler, S. R., Weinrib, A. Z., Azam, M. A., \& Katz, J. (2018). The use of acceptance and commitment therapy in oncology settings: A narrative review. Psychological Reports, 121(2), 229-252. doi: 10.1177/0033294117726061.

Fledderus, M., Bohlmeijer, E. T., Pieterse, M. E., \& Schreurs, K. M. G. (2012). Acceptance and commitment therapy as guided self-help for psychological distress and positive mental health: A randomized controlled trial. Psychological Medicine, 42(3), 485-495. doi: 


\section{$10.1017 /$ S0033291711001206}

Harris, R. (2006). Embracing your demons: An overview of acceptance and commitment therapy. Pychotherapy in Australia, 12(4), 1-8.

Hayes, C., Steven, \& Smith, S. (2005). Get out of your mind and into your life: The new acceptance and commitment therapy. Oackland: New Harbinger Publications Inc.

Hayes C., Steven, Strosahl D., Kirk, \& Wilson G., K. (2016). Acceptance and commitment therapy: second edition: The process and practice of mindful change. New York: Guilford Press.

Hayes, S. C., Luoma, J. B., Bond, F. W., Masuda, A., \& Lillis, J. (2006). Acceptance and commitment therapy: Model, processes and outcomes. Behaviour Research and Therapy, 44(1), 1-25. doi: 10.1016/j.brat.2005.06.006.

Hayes, S. C., Strosahl, K. D., Bunting, K., Twohig, M., \& Wilson, K. G. (2004). What is acceptance and commitment therapy? in a Practical Guide To Acceptance And Commitment Therapy (pp. 3-29). doi: 10.1007/978-0-387-23369-7_1.

Hope, V., \& Henderson, M. (2014). Medical student depression, anxiety and distress outside north america: A systematic review. Medical Education, 48(10), 963-979. doi: 10.1111/medu.12512.

Ismoyowati, T. W. (2018). Pengaruh acceptance and commitment theraphy terhadap perubahan kecemasan dan self efficacy pada pasien dengan Hemodialisa di RS Saint Carolus Jakarta. Jurnal Kesehatan, 5(2), 44-58. doi: 10.35913/jk.v5i2.95.

Kaplan, H. ., Saddock, B. ., \& Grebb, J. . (2010). Sinopsis psikiatri; Ilmu pengetahuan perilaku psikiatri klinis (W. Kusuma, Ed.). Jakarta: Bina Rupa Aksara.

Kusumawardhani, S. J., \& Poerwandari, E. K. (2019). Efektivitas acceptance commitment therapy dalam meningkatkan subjective well-being pada dewasa muda pasca putusnya hubungan pacaran. Jurnal Ilmiah Psikologi MIND SET, 9(01), 78-97. doi: 10.35814/mindset.v9i01.727.

Luoma, J. B., \& Platt, M. G. (2014). Shame, self-criticism, self-stigma, and compassion in Acceptance and Commitment Therapy. doi: 10.1016/j.copsyc.2014.12.016.

Orsillo, S. M., \& Batten, S. V. (2005, January). Acceptance and commitment therapy in the treatment of posttraumatic stress disorder. Behavior Modification, Vol. 29, pp. 95-129. doi: 10.1177/0145445504270876.

Shaluhiyah, Z., Musthofa, B. S., \& Widjanarko, B. (2015). Stigma masyarakat terhadap orang dengan HIV/AIDS. Kesmas: Jurnal Kesehatan Masyarakat Nasional, 9(4), 333-339.

Tania, M., \& Hernawaty, T. (2018). Penggunaan acceptance and commitment therapy (ACT) terhadap kecemasan narapidana wanita: Systematic Review. Jurnal Keperawatan BSI, 6(2), 122-129. Retrieved from http://ejournal.bsi.ac.id/ejurnal/index.php/jk.

Yadavaia, J. E., Hayes, S. C., \& Vilardaga, R. (2014). Using acceptance and commitment therapy to increase self-compassion: A randomized controlled trial. Journal of Contextual Behavioral Science, 3(4), 248-257. doi: 10.1016/j.jcbs.2014.09.002. 